\title{
SECRETION OF HUMAN CHORIONIC GONADOTROPHIN BY THE EARLY PLACENTA IN VITRO
}

\author{
L. G. PATRITO, A. FLURY, J. ROSATO AND A. MARTIN \\ Cátedra de Química Biologica Analítica, Departamento de Bioquímica Clínica, \\ Facultad de Ciencias Químicas, Universidad Nacional de Córdoba, \\ Laboratorio Central, Hospital Nacional de Clínicas, \\ Santa Rosa 1564, Córdoba, Argentina
}

(Received 4th March 1975)

\begin{abstract}
Summary. The secretion in vitro of HCG and proteins was studied in fragments of placenta from women in the first trimester of pregnancy by a pulse-chase system. A 10 -min pulse with $\left[{ }^{3} \mathrm{H}\right]$ leucine was used. It was concluded that the approximate half-time of release for HCG was 150 min. Proteins precipitable with trichloroacetic acid had a bi-exponential pattern, the half-times of release being 100 and $270 \mathrm{~min}$. These rates of release indicate that the HCG produced by the early placenta was rapidly passed into the circulation rather than stored.
\end{abstract}

Previous studies have established that HCG and proteins synthesized in vitro by placental tissue taken from women in the first trimester of pregnancy are secreted into the incubation media (Benagiano et al., 1972; Patrito et al., 1973).

The rate of release of these macromolecules is not known and difficult to study in women in vivo, because the amount of radioactive material to be administered may be hazardous (Lerner et al., 1971). Moreover, the values may be a reflection of maternal or fetal rather than placental function (Klopper, 1969). Therefore we have used the in-vitro pulse-chase system developed by Meldolesi $e t$ al . (1972) and Samli \& Lai (1973) to study the secretion of prolactin and growth hormone from rat pituitaries. The tissue is given a radioactive label for a short period of time, and the transport of a constant amount of radioactive molecule can be subsequently followed (Schramm, 1967).

Placentae were obtained from five women in the first trimester of pregnancy after therapeutic abortion induced by curettage. Tissues were collected in cold Ringer solution and used within $1 \mathrm{hr}$. Fragments of each placenta, weighing approximately 5 to $10 \mathrm{mg}$, were washed several times with cold Krebs-Ringer bicarbonate, $\mathrm{pH} 7 \cdot 2$ (Krebs, 1950). Aliquots of $100 \mathrm{mg}$ were placed in $15-\mathrm{ml}$ Ehrlenmeyer flasks containing $1 \mathrm{ml}$ Krebs-Ringer bicarbonate and $8 \mu \mathrm{Ci}$ L- $\left[4,5-{ }^{3} \mathrm{H}\right]$ leucine (sp. act. $41 \cdot 2 \mathrm{Ci} / \mathrm{mmol}$ ) (New England Nuclear Corporation). The flasks were left in a cold water-bath for $15 \mathrm{~min}$ and then pulse-labelled for $10 \mathrm{~min}$ at $37^{\circ} \mathrm{C}$ in an atmosphere of $95 \% \mathrm{CO}_{2} / 5 \% \mathrm{O}_{2}$ in a shaking bath at 1.5 cycles/sec. The fragments of placenta were then separated from the radioactive incubation media, washed three times with large volumes of warm in- 
cubation medium containing 760 -fold excess cold leucine (chase medium), and reincubated in the chase medium for $15,30,60,120$ or $240 \mathrm{~min}$.

At the end of incubation, the media were separated from the tissues, which were then washed several times and homogenized with $1 \mathrm{ml}$ chase medium. The media and homogenized tissues were centrifuged at $20,000 \mathrm{~g}$ at $4^{\circ} \mathrm{C}$ and the corresponding supernatants used for subsequent analysis.

The isolation of labelled HCG was performed as described by Patrito et al. (1973) using 100 i.u. HCG carrier and antiserum to HCG according to its titre. The precipitate obtained was washed twice with Krebs-Ringer bicarbonate, then dissolved in $0.1 \mathrm{M}-\mathrm{NaOH}$, precipitated with the same volume of $10 \%$ of trichloroacetic acid (TCA) and finally washed as for total proteins.

Table 1. Effect of different preincubation periods on the incorporation and secretion of $\left[{ }^{3} \mathrm{H}\right]$ leucine into HCG and total proteins by fragments of placenta taken from women in the first trimester of pregnancy during incubation for $30 \mathrm{~min}$

\begin{tabular}{ccccccc}
\hline \multirow{2}{*}{$\begin{array}{c}\text { Preincubation time } \\
(\text { min })\end{array}$} & \multicolumn{2}{c}{$\begin{array}{c}\text { HCG } \\
\left.\text { ct/min } \times 10^{-2} / g\right)\end{array}$} & & \multicolumn{2}{c}{$\begin{array}{c}\text { Total protein } \\
\left\langle c t / \text { min } \times 10^{-2} / g\right)\end{array}$} \\
\cline { 2 - 3 } \cline { 5 - 6 } & Tissue & Medium & & Tissue & Medium \\
\hline 0 & $144 \pm 18^{*}$ & $244 \pm 49$ & & $754 \pm 54$ & $1206 \pm 140$ \\
30 & $126 \pm 13$ & $227 \pm 51$ & & $697 \pm 31$ & $988 \pm 122$ \\
60 & $119 \pm 16$ & $187 \pm 38$ & & $618 \pm 44$ & $1131 \pm 155$ \\
120 & $134 \pm 11$ & $202 \pm 43$ & & $754 \pm 38$ & $1006 \pm 98$ \\
240 & $110 \pm 21$ & $214 \pm 55$ & & $707 \pm 46$ & $1115 \pm 114$ \\
\hline
\end{tabular}

* Values are the means \pm S.D. for three different placentae.

For the isolation of radioactive proteins equal volumes of $10 \%$ TCA were added to $0.2 \mathrm{ml}$ of medium or tissue supernatants. The mixture was centrifuged at $3000 \mathrm{~g}$ for $20 \mathrm{~min}$ and the supernatants were used for determination of the radioactivity of TCA-soluble proteins. The precipitates were washed twice with $5 \%$ TCA containing $0.01 \mathrm{~m}$ cold leucine, dissolved with $0.1 \mathrm{M}-\mathrm{NaOH}$, precipitated again with TCA up to $5 \%$ concentration, and finally washed with ether and solubilized in $0.2 \mathrm{ml} 0.1 \mathrm{M}-\mathrm{NaOH}$. Aliquots of $0.1 \mathrm{ml}$ were incorporated into $10 \mathrm{ml}$ dioxane containing $0.2 \%$ of 2,5-diphenyloxazol (PPO) and $10 \%$ naphthalene. The remaining aliquots were used for assessment of the protein content by the method of Lowry et al. (1951). A control sample was pulselabelled in the same way, but with the addition of $20 \mathrm{~mm}$ cold leucine. The radioactivity obtained was subtracted from that of the samples.

In preliminary experiments, the viability of placental cells was checked by determining their rate of incorporation of $\left[{ }^{3} \mathrm{H}\right]$ leucine into HCG and total proteins for periods of incubation similar to those in the chase assays. The fragments were first preincubated for $30,60,120$ or 240 min with Krebs-Ringer bicarbonate without radioactive leucine. The tissues were then incubated for 30 min with the radioactive leucine and the amount of synthesized HGG and total proteins measured in tissues and media. As shown in Table 1, the amount of radioactivity remaining in the tissue and secreted into the medium was similar for all the preincubation periods. 
The distribution of pulse-labelled HCG and total proteins during the chase incubation is shown in Text-fig. 1. The radioactivity decreased in the tissue and increased in inverse proportion in the medium during incubation. The $\mathrm{ct} / \mathrm{min}$ of tissue plus medium for each period of incubation was considered as $100 \%$, and the half-times for release of labelled HCG and proteins were calculated as shown in Text-fig. 2. The approximate half-time of $\mathrm{HCG}$ release was $150 \mathrm{~min}$. There appeared to be a bi-exponential release of total proteins into the medium: a fast phase during the first $60 \mathrm{~min}$ of chase with a half-time of release of 100 min, and a slow phase with a half-time of release at $270 \mathrm{~min}$ of chase.

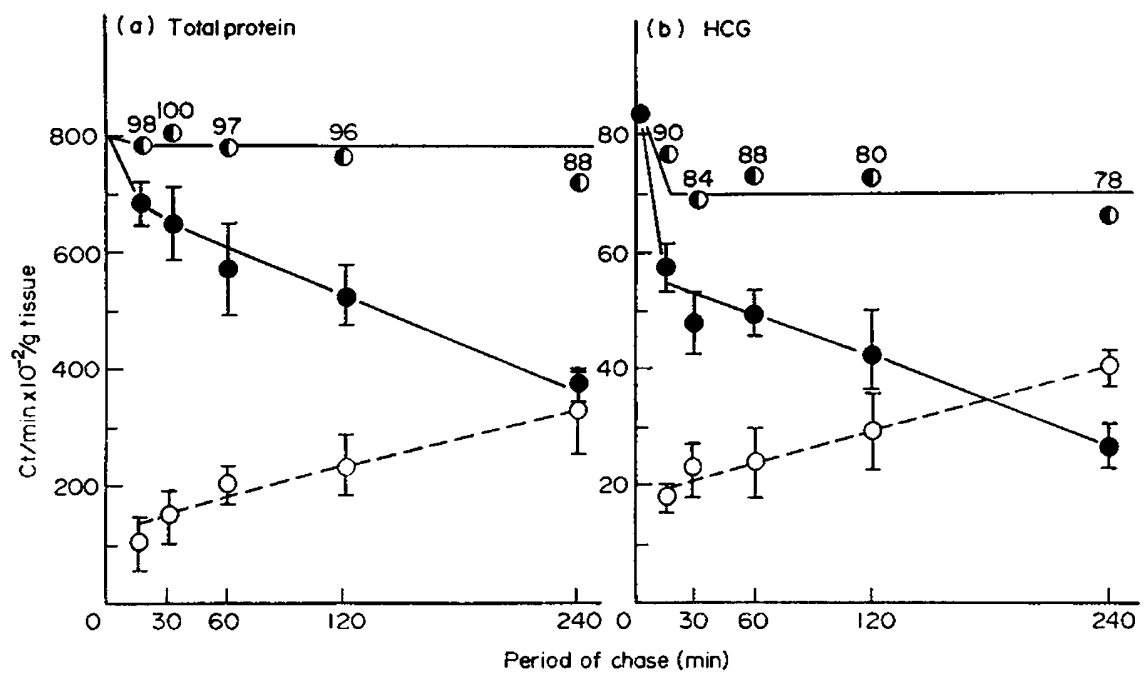

TEXT-FIG. 1. The distribution in vitro of pulse-labelled (a) TCA-precipitable protein and (b) HCG between tissue and medium, as a function of minutes of chase, in early human placenta. Vertical bar represent the S.D. for five placentae. $\boldsymbol{D}$, Total labelled protein or HCG in tissue plus medium; $\bullet$, total labelled protein or HCG in tissue; 0 , total labelled protein or HCG in medium. The numbers on the graph represent the \% of total proteins/HCG in tissue plus medium at the corresponding time of the chase, when compared with the value of the pulse $(10 \mathrm{~min})$ as $100 \%$.

The incorporation of labelled amino acid into HCG and total proteins after the pulse-labelling was checked by determining its specific activity in ct $/ \mathrm{min}$ in the tissue plus medium/g of tissue. There was no change during the chase period, but a consistent drop of 10 to $20 \%$ as compared with the pulse label was found by the end (Text-fig. 1).

The radioactivity (ct/min/mg protein) of the TCA-soluble, and the TCAprecipitable proteins in the tissue and in the tissue plus medium, respectively, remained unchanged during the chase periods. There was a parallelism between the values for TCA-insoluble and TCA-soluble proteins, but the levels of the latter were lower.

The present study shows that, during a short pulse period, fragments of early human placenta incorporated $\left[{ }^{3} \mathrm{H}\right]$ leucine into $\mathrm{HCG}$ and other TCA-precipitable proteins which were later released at different rates into the chase medium. The bi-exponential pattern of release of total proteins indicates the existence of at least two different pools of material in the placenta. 


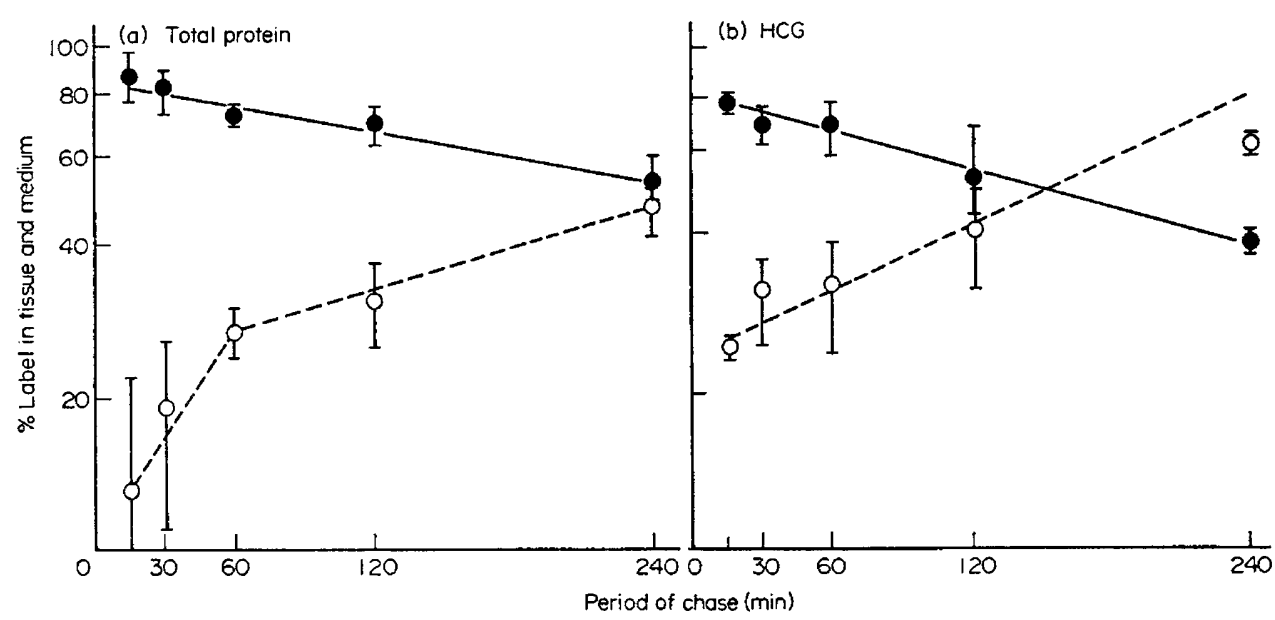

Text-Fig. 2. Percentage of pulse-labelled (a) TCA-precipitable protein, and (b) HCG in tissue and medium in a chase experiment on human placental tissue after a pulse of 10 min. $\bullet$, In tissue; $O$, in medium. Vertical bars represent the S.D. for five placentae.

The possibility of re-synthesis of HCG and total proteins after pulse-labelling, leading to an overestimate of release, was avoided by using an excess of cold leucine in the chase medium. Unmodified specific activity during the chase indicated that re-synthesis had not occurred. The viability experiments showed the integrity of the cellular system. The fairly constant values of radioactivity obtained in tissue and media at different times suggest that the synthesized HCG and total proteins were not leaked into the chase medium.

The significance of the short time of release obtained for HCG under the experimental conditions described supports the idea (Patrito et al., 1973) that the hormone produced was not accumulated in the cells, but was rapidly secreted.

This work was supported partly by a grant from Consejo Nacional de Investigaciones Científicas y Técnicas, Argentina. We wish to thank Dr Edgar Nowotny for the help throughout the course of this work.

\section{REFERENCES}

Benagiano, G., Pala, A., Meirinho, M. \& Ermini, M. (1972) Biosynthesis of human chorionic gonadotrophin in vitro: incorporation of $\left[{ }^{14} \mathrm{C}\right] \mathrm{L}-$ leucine. $\mathcal{F}$. Endocr. 55, 387-396.

KLOPPER, A. (1969) The assessment of placental function in clinical practice. In Foetus and Placenta, p. 472. Eds A. Klopper \& E. Diczfalusy. Blackwell Scientific Publications, Oxford.

KREBs, H.A. (1950) Body size and tissue respiration. Biochim. biophys. Acta 1, 249-269.

Lerner, U., SAxena, B.N. \& Diczralusy, E. (1971) Extracorporeal perfusion of the human foetus, placenta and foeto-placental unit. In Perfusion Techniques, p. 311. Ed. E. Diczfalusy. Bogtrykkeriet Forum, Copenhagen.

Lowry, O.H., Rosebrough, N.J., FarR, A.L. \& Randali, R.J. (1951) Protein measurement with the Folin phenol reagent. F. biol. Chem. 193, 265-275.

Meldolesi, J., Marini, D. \& Demonte Marini, M.L. (1972) Studies on in vitro synthesis and secretion of growth hormone and prolactin. I. Hormone pulse labeling with radioactive leucine. Endocrinology 91, 802-808.

Patrito, L.C., Flury, A., Rosato, J. \& Martín, A. (1973) Biosynthesis in vitro of chorionic gonadotrophin from human placenta. Hoppe-Seyler's Z. physiol. Chem. 354, 1129-1132.

SAmLI, M. H. \& LAI, M.-F. (1973) Protein synthesis in the rat anterior pituitary. III. The fate of total protein, prolactin and growth hormone labeled in an in vitro incubation. Endocrinology 93, 767-776.

Schram, M. (1967) Secretion of enzymes and other macromolecules. A. Reo. Biochem. 36, 307-320. 